\title{
Assembling Alumbradismo: The Evolution of a Heretical Construct ${ }^{1}$
}

\author{
Jessica J. Fowler
}

The heresy of Alumbradismo is far from an unknown topic of study, but it remains one of the most confusing terms in Spanish historiography. ${ }^{2}$ It has appeared in general studies of the Spanish Inquisition since the beginning of the twentieth century. ${ }^{3}$ An increasing interest in this heresy as part of, and contributing to, a broader and more nuanced assessment of the Spanish spiritual climate of the sixteenth century produced a number of important articles in the mid-twentieth century. ${ }^{4}$ Larger studies of these specific heretics and their beliefs would appear beginning in the late 1970s. ${ }^{5}$ This trend was quickly followed by efforts to make the inquisitorial documents dealing with Alum-

1 The research leading to these results has received funding from the European Research Council under the European Union's Seventh Framework Programme (FP7/2007-2013) ERC Grant Agreement number 323316, project CORPI 'Conversion, Overlapping Religiosities, Polemics, Interaction. Early Modern Iberia and Beyond'. The author would also like to thank the tutors and participants of the 2015 Summer Academy of Atlantic History for their comments and suggestions on this paper.

2 Alison Weber, 'Demonizing Ecstasy: Alonso de la Fuente and the Alumbrados of Extremadura', in The Mystical Gesture: Essays on Medieval and Early Modern Spiritual Culture in Honor of Mary E. Giles, (ed.) Robert Boenig (Aldershot: Ashgate, 2000), p. 141.

3 Among others see Marcelino Menéndez Pelayo, Historia de los Heterodoxos Españoles (Madrid: Librería General de Victoriano Suárez, 1911); Henry Charles Lea, A History of the Inquisition of Spain (New York: The Macmillan Company, 1907); Henry Kamen, The Spanish Inquisition: A Historical Revision (New Haven: Yale University Press, 1998).

4 Among these works see Melquíades Andrés Martín, 'Recogidos y alumbrados. Nueva visión conjunta del alumbradismo español', Salmanticensis, 21 (1974): pp. 151-63, and Andrés Martín, 'Los alumbrados de Toledo según el proceso de María de Cazalla (1532-34)', Cuadernos de Investigación Histórica, 8 (1984): pp. 65-81; José C. Nieto, 'The Heretical Alumbrados Dexados: Isabel de la Cruz and Pedro Ruiz de Alcaraz', Revue de littérature comparée, 52 (1978): pp. 293313; Ángela Selke de Sánchez, 'Algunos datos nuevos sobre los primeros alumbrados: el edicto de 1525 y su relación con el proceso de Alcaraz', Bulletin Hispanique, 54 (1952): pp. $125^{-52}$.

5 Alvaro Huerga, Historia de los a lumbrados, 5 vols. (Madrid: FUE, 1978-94); Alastair Hamilton, Heresy and Mysticism in Sixteenth-Century Spain: The Alumbrados (Toronto: University of Toronto Press, 1992); Bernardino Llorca, La Inquisición Española y los Alumbrados (1509-1667)

(C) JESSICA J. FOWLER, 2016 | DOI 10.1163/9789004324329_011

This is an open access chapter distributed under the terms of the CC-BY-NC-ND License. 
bradismo accessible to a larger audience, resulting in the publication of source material relating to this heresy, specifically the procesos of at least some of the accused. ${ }^{6}$ This immense historiography most often focuses on the group identified as Alumbrados in 1520's Toledo, occasionally mentioning the next appearance of the heresy in Extremadura, but rarely making any effort to understand how and why the heresy continued to appear sporadically in Spain and its colonial holdings during the rest of the sixteenth century and beyond. ${ }^{7}$ Studying individual manifestations of alumbradismo in a particular time and place has left us with a fractured understanding of what the Spanish Inquisition understood as a coherent and unified sect.

The initial group that became known as Alumbrados lacked a formal statement of doctrine or clear leader. The understanding that they constituted a distinct heretical sect was the product of the Spanish Inquisition's efforts to identify, define, and categorize suspicious individuals in and around Toledo in the 1520 . There was no such thing as an Alumbrado heresy, or even an Alumbrado heretic, until the Inquisition elected to identify and persecute them. As R.I. Moore points out in The Formation of a Persecuting Society, 'heresy exists only in so far as authority chooses to declare its existence.8 Thus, from its inception, the heresy of Alumbradismo and the supposed threat it posed was a construct of the Inquisition that would develop and evolve over the course of the sixteenth century: 'The Inquisition created the vocabulary of

(Salamanca: Universidad Pontificia de Salamanca, 1980); Antonio Márquez, Los alumbrados, orígenes y filosofía, 1525-1559 (Madrid: Taurus, 1980).

6 See Milagros Ortega-Costa, Proceso de la Inquisición contra María de Cazalla (Madrid: FuE, 1978); Javier Pérez Escohotado, Antonio de Medrano, alumbrado epicúreo. Proceso inquisitorial (Toledo, 1530) (Madrid: Verbum, 2003); Alastair Hamilton, El proceso de Rodrigo de Bivar (1539) (Madrid: FUE, 1979); Lu Ann Homza (ed. and trans.), The Spanish Inquisition, 1478-1614: An Anthology of Sources (Cambridge: Hackett Publishing Company, 2006) among others.

7 Occasionally some of the historiography has treated the second manifestation of Alumbradismo in the Extremadura as a way to close their discussion of the Toledo group. General studies of the Inquisition in the Spanish colonies regularly mention Alumbrado cases that appear within the particular jurisdiction under study. Specific studies about this heresy in Mexico include Adriana Rodríguez Delgado, Santos o embusteros. Los alumbrados novohispanos del siglo XVII (Mexico: Estado de Veracruz, 2013); and Nora Jaffary, False Mystics: Deviant Orthodoxy in Colonial Mexico (Lincoln: University of Nebraska Press, 2004). For an effort to start understanding Alumbradismo within a more imperial context see Mercedes GarcíaArenal and Felipe Pereda, 'On the Alumbrados: Confessionalism and Religious Dissidence in the Iberian World', in The Early Modern Hispanic World: Transnational and Interdisciplinary Approaches, (ed.) Kimberly Lynn and Erin Rowe (Cambridge: Cambrige University Press, 2016), pp. 119-50.

8 Robert I. Moore, The Formation of a Persecuting Society: Authority and Deviance in Western Europe, 950-1250 (Malden: Blackwell Publishing, 2007), p. 64. 
the Alumbrado heresy, taught it to the public, who denounced practitioners in their communities, and catalogued its existence in trial proceedings. ${ }^{9}$

This essay unites the manifestations of Alumbradismo in Spain and New Spain during the sixteenth century to demonstrate how the Inquisition's definition of the heresy could evolve and spread without impairing the fundamental understanding of it as a coherent and unified sect. Grouping together the Alumbrados of the $15^{20}$, a group of Converso beatas and their male followers who practiced an interior spirituality devoid of any form of external expression, with those of the 1590s, a sensual cadre of religious men leading groups of beatas who experienced public raptures and ecstasies, has led many historians to dismiss the charge as a catch-all encompassing such a plethora of deviant behaviors and practices that it became effectively meaningless by the late sixteenth century. ${ }^{10}$ Such an assessment, however, fails to consider the inquisitorial reasoning that occurred between these dates which would explain the conglomeration of these seemingly disparate religious trends. A better approach would consider the larger context created by the Inquisition in its efforts to prosecute those it labeled as Alumbrados as well as the inquisitorial logic and processes that contributed to understanding these groups as analogous. Too often historians reproduce the categories used by the Inquisition without examining the development, or even exact meaning, of these classifications, assuming them to be static entities. ${ }^{11}$ Rather than becoming too vague to be meaningful, the charge of Alumbradismo developed over time, as most understandings of heterodoxy do, and its evolution is clearly traceable through the sixteenth century. The documentation pertaining to this alleged sect demonstrates a clear progression of inquisitorial thought as individuals and experiences contributed to redefining the parameters of what constituted this heresy. However, ideas were not enough to generate heretics. The appearance of Alumbrados throughout the sixteenth century required not only a definition of this heresy, even if it was evolving, but also individuals willing to work

9 Jaffary, False Mystics, p. 16.

$10 \quad$ Hamilton, Heresy and Mysticism, p. 91; Adelina Sarrión Mora, Beatas y endemoniadas. Mujeres heterodoxas ante la Inquisición, siglos XVI a XIX (Madrid: Alianza, 2003), pp. 196, 213; Jacqueline Holler, 'More Sins than the Queen of England: Marina de San Miguel Before the Mexican Inquisition', in Women in the Inquisition: Spain and the New World, (ed.) Mary E. Giles (Baltimore: Johns Hopkins University Press, 1999), p. 220; Helen Rawlings, The Spanish Inquisition (Malden: Blackwell Publishing, 2006), p. 92.

11 Mercedes García-Arenal, 'Creating Conversos: Genealogy and Identity as Historiographical Problems', Bulletin for Spanish and Portuguese Historical Studies, 38, no. 1 (2013): pp. 1-19, esp. p. 4. 
with, and sometimes for, the Inquisition to ensure its eradication..$^{12}$ Alumbrados and their 'heretical deviance was not something to be discovered; it was something to be constructed from the interplay of social anxieties as well as competing personal and institutional agendas. ${ }^{\prime 3}$

\section{Formulating Alumbradismo: Toledo, 1520s-1530s}

The heresy of Alumbradismo was officially formulated by the Spanish Inquisition in 1525 to denominate a group of suspects preaching and practicing an interiorized and antinomian spirituality in and around Toledo. The threat posed by these individuals seemed particularly potent considering the religious milieu of the moment. After decades of aggressive activity against Conversos and their alleged judaizing practices, the Spanish Inquisition had checked the most obvious excesses that had originally inspired the institution's founding. However, the fact that the majority of suspects eventually designated as Alumbrados were Conversos stirred old suspicions about the New Christian population and their heretical proclivities. ${ }^{14}$ Further complicating the suspects' position was their advocation of an interior spirituality. A strong reform movement spearheaded by the Franciscan order had recently enjoyed the patronage of some of the highest ranking Spanish ecclesiastics, including Cardinal Francisco Jiménez de Cisneros, and this had led to an

12 Important recent works demonstrate the key role individuals played within the institutional apparatus of the Inquisition. See Kimberly Lynn, Between Court and Confessional: The Politics of Spanish Inquisitors (Cambridge: Cambridge University Press, 2013); Sara T. Nalle, Mad for God: Bartolomé Sánchez, The Secret Messiah of Cardenete (Charlottesville: University of Virginia Press, 2001); also sincere thanks to Sara T. Nalle for sharing her forthcoming piece, 'A Forgotten Campaign Against the Conversos of Sigüenza: Pedro Cortés and the Inquisition of Cuenca', in Conversos and Moriscos in Late Medieval Spain and Beyond. Vol.3, (ed.) Kevin Ingram (Leiden: Brill, forthcoming).

13 Alison Weber, 'The Inquisitor, the Flesh and the Devil: Alumbradismo and Demon Possession', in Dämonische Besessenheit: Zur Interpretation eines kulturhistorischen Phänomens, (ed.) Hans de Waardt (Bielefeld: Verlag für Regionalgeschichte, 2005), pp. 177-91, esp. p. 189 .

For further reading about the converso matrix from which alumbrado beliefs emerged, see Stefania Pastore, Una herejía española, conversos, alumbrados e Inquisición (1449-1559) (Madrid: Marcial Pons, 2010); Maria Laura Giordano, Apologetas de la Fe. Élites conversas entre Inquisición y patronazgo en España (siglo XV y XVI) (Madrid: FUE, 2004); Ángela Selke, 'El iluminismo de los conversos y la Inquisición. Cristianismo interior de los alumbrados, resentimiento y sublimación', in La Inquisición española. Nueva visión, nuevos horizontes, (ed.) Joaquín Pérez Villanueva (Madrid: Siglo Veintiuno, 1980). 
increasing interest in forms of interior devotion. In fact, efforts to differentiate between the practices of recogimiento (recollection) and the more extreme dejamiento (abandonment) were put to particularly polemical use in efforts to define, denigrate, and delineate what became known as Alumbradismo from other more orthodox practices..$^{15}$ Such reforms also made Spain a particularly fertile ground for the critiques of Erasmus, at least at the beginning of the century, although his influence would quickly wither in the face of the Lutheran threat. ${ }^{16}$ After the Diet of Worms and Martin Luther's immediate excommunication in 1521, it became clear that reconciliation with the Catholic Church was impossible, and Carlos V ordered the confiscation of all Lutheran works in Spain. However, this prohibition required reiteration in 1525 , just six months before the official condemnation of Alumbrados, after news that Luther's works were nonetheless finding their way into Spain. ${ }^{17}$ The religious atmosphere which had previously favored calls for reform within the Church was suddenly confronted with the incontrovertible fact that such efforts could produce unintended results. Those accused as Alumbrados, and the spirituality they supposedly espoused, found themselves located at the nexus of these diverse trends. Most of the accused were Conversos with strong ties both personally and spiritually to the reformed Franciscans and who, in some cases, admitted enjoying the works of Erasmus, which only augmented suspicions about their potential Lutheranism. ${ }^{18}$ This left these individuals in a particularly liminal position: outside the bounds of strict orthodoxy but without precisely conforming to previously created categories of deviance. ${ }^{19}$

15 There is an extensive historiography on these forms of spirituality. On its relation to Alumbradismo see Andrés Martín, 'Recogidos y alumbrados'; Hamilton, Heresy and Mysticism, pp. 29-32; Moshe Sluhovsky, Believe Not Every Spirit: Possession, Mysticism and Discernment in Early Modern Catholicism (Chicago: University of Chicago Press, 2007), pp. 102-12.

16 Marcel Bataillon, Erasmo y España, (trans.) Antonio Alatorre (Mexico: Fondo de Cultura Económica, 1950), p. 72.

17 Bataillon, Erasmo y España, p. 19o; Selke, 'Algunos Datos', p. 130; Lu Ann Homza, Religious Authority in the Spanish Renaissance (Baltimore: Johns Hopkins University Press, 200o). In fact, initially, the fiscal Diego Ortiz de Angulo worked diligently to convince the inquisitors that Judaizing should be among the list of charges applied to at least some of the accused, but he ultimately failed. Giordano, Apologetas de la Fe, p. 143; Hamilton, Heresy and Mysticism, pp. 69-71.

The historiography of the Toledo Alumbrados is brimming with discussions about which of these religious tendencies had the greatest impact on what became known as the heresy of Alumbradismo and in what ways. Some of the most enlightening recent work includes Stefania Pastore, Una herejía española and María Laura Giordano, Apologetas de la Fe. The work of Marcel Bataillon, Erasmo y España is the classic text relating to the role of Erasmianism on the Alumbrados, but it has not gone unchallenged, see Eugenio 


\section{A Category Created, Perpetrators Punished: An Edict, an Auto de Fe}

The inability to strictly classify this group as Lutherans or Erasmians or Judaizers forced the Inquisition to construct a novel heretical identity for these individuals. Thereafter, it would be incorporated into the Inquisition's General Edicts of Faith which were periodically read aloud to the public to teach them about the heretical practices the institution was interested in pursuing. ${ }^{20}$

The Inquisition's mandate to enforce orthodoxy required it to delineate and categorize that which failed to correspond to this mold: 'In a society defined by faith the power of defining the faith itself was the key to every door. ${ }^{21}$ This need was especially acute during periods of breakdown or questioning of traditional religious categories. ${ }^{22}$ At no time was Catholicism a monolith, despite the Church's best efforts, and the parameters of orthodoxy were neither fixed nor always agreed upon. Spiritual practices and opinions only became 'heresy when authorities declare[d] it intolerable. ${ }^{23}$ Once this occurred, the Inquisition had to provide concrete classifications and definitions, based on institutional memory as well as contemporary investigations, of who and what was to be persecuted. ${ }^{24}$ Formulating heretical identities and categories for these groups facilitated the Inquisition's work of persecution, while producing knowledge about heresy. Even repression had productive qualities..$^{25}$ These novel descriptions of heresy were then codified in inquisitorial records and confirmed through the public punishment of those the Inquisition elected to place within

Asensio, El erasmismo y las corrientes espirituales afines; conversos, franciscanos, italianizantes (Salamanca: SEMYR, 200o). The work of Márquez, Los alumbrados is obviously seminal to any discussion of alumbrado beliefs and origins.

A similar process occurred during the high Middle Ages with the Free Spirit heresy. Robert E. Lerner, The Heresy of the Free Spirit in the Later Middle Ages (Berkeley: University of California Press, 1972), pp. 39, 83. Robert I. Moore, The War on Heresy (Cambridge: Belknap Press, 2012), p. 150. Talal Asad, 'Medieval Heresy: An Anthropological View', Social History, 11 (1986): pp. 34562.

Moore, Formation of a Persecuting Society, p. 64. See also Elia Nathan Bravo, 'La Inquisición como generadora y trasmisora de ideologías', in Inquisición novohispana, (ed.) Noemí Quezada, M. Eugenia Rodríguez and Marcela Suárez (Mexico: UNAM, 2000), p. 280. Nathan Bravo reminds us that it was actually incipient persecution that led to a definition of delinquents and not the other way around, and that this definition then provided a means to justify and amplify its persecution; 'La Inquisición como generadora', p. 279.

25 Michel Foucault, Power/Knowledge: Selected Interviews and Other Writings, 1972-1977 (New York: Pantheon Books, 1980), pp. 51-52. 
these new categories. ${ }^{26}$ In turn, this entire process verified the need for the Inquisition's continued existence as it became obvious that the heretical threats it identified were indeed real and required persecution. This procedure resulted in the Inquisition's ability to take on its own impetus after identifying a deviant group by forcing itself into the position of guarantor of the sect's existence. ${ }^{27}$ By releasing the Edict of Faith of 1525 the Spanish Inquisition set this process into motion for the heresy of Alumbradismo. However, this is not to say that those prosecuted under this charge in the following years were not actually deviating from Catholic orthopraxis. The Inquisition did not create their heterodox behavior but rather constructed a heretical identity for them so that they could be effectively persecuted. Such identification by the Inquisition provided a level of cohesion and coherence for groups, including Alumbrados, which they were incapable of claiming independent of or before their persecution..$^{28}$ Alumbrados became a menacing heretical sect only when the Inquisition identified them as such despite the fact that they would not have identified themselves with either the name 'alumbrados' nor recognized themselves as a unified group with shared beliefs. ${ }^{29}$ In this sense, the Spanish Inquisition constructed the heretical identity and discourse of an Alumbrado sect.

According to the 1525 Edict of Faith which allegedly outlined their beliefs, the Alumbrados rejected exterior manifestations of faith and proscribed Catholic rituals believing that salvation did not require intermediaries between the individual and God. They renounced the veneration of images, lowered their eyes during the consecration of the host, denounced fasts and good works as unnecessary, advocated mental over oral prayer, and proclaimed confession

26 Moore, Formation of a Persecuting Society, p. 184; John Arnold, Inquisition and Power: Catharism and the Confessing Subject in Medieval Languedoc (Philadelphia: University of Pennsylvania Press, 2001), pp. 54-56, 76-9o. Gustav Henningsen, The Witches' Advocate: Basque Witchcraft and the Spanish Inquisition, 1609-1614 (Reno: University of Nevada Press, 1980), p. 208.

28 Moore, Formation of a Persecuting Society, p. 67.

29 Similar ideas have been pursued in relation to other forms of religious deviance by various authors. In addition to what has been cited earlier in this paragraph and an immense and well-developed historiography concerning witchcraft see also Carlo Ginzburg, The Night Battles: Witchcraft and Agrarian Cults in the Sixteenth and Seventeenth Centuries (Baltimore: Johns Hopkins University Press, 1983); Mark Gregory Pegg, The Corruption of Angels: The Great Inquisition of 1245-1246 (Princeton: Princeton University Press, 2001); James Buchanan Given, Inquisition and Medieval Society: Power, Discipline and Resistance in Languedoc (Ithaca: Cornell University Press, 1997); Lerner, Heresy of the Free Spirit. 
to be a man-made rather than divine law. They spoke out against the taking of holy vows and claimed that in the 'matrimonial act' couples were closer to God than when in prayer. However, with the exception of one beata, the group was not known for indulging in illicit sexual behaviors. ${ }^{30}$ They mocked those who gesticulated during the celebration of the Mass, saying it was nothing but playing with the body in church. ${ }^{31}$ Some of the leading figures of the supposed Alumbrados were even known for reproaching certain Franciscans for the scandal caused when they experienced public raptures and ecstasies. Again, apart from the beata already noted for her sexual impropriety, the first alleged Alumbrados did not claim to experience visions, revelations, or any sort of somatic experiences considered indicative of divine favor or gifts. ${ }^{32}$

Deciding how to handle these suspects produced a range of opinions. In the case of Pedro Ruiz de Alcaraz, considered to be one of the leaders of the group, thirteen judges were consulted regarding his punishment. Of these, seven voted that he be 'relaxed to the secular arm' and burned for his heretical crimes, while the other six were more merciful in their judgments. ${ }^{33}$ Among these harsh judges was the Dominican maestro Juan de Ochoa, a permanent member of the esteemed Colegio de Santo Tomás in Seville since 1520. He would later take up a position in the University of Osuna before returning as regent to the Colegio de Santo Tomás. During his tenure in Seville he participated in identifying the first Protestant cell in the area and was later called upon to assess some of the most complex theological cases of the period, including those of Juan de Vergara and Bartolomé de Carranza. ${ }^{34}$ Ochoa was a well-

30 Mary E. Giles, 'Francisca Hernández and the Sexuality of Religious Dissent', in Women in the Inquisition: Spain and the New World, (ed.) Mary E. Giles (Baltimore: Johns Hopkins University Press, 1999), pp. 75-97.

31 Copies of the Edict of Faith can be found reprinted in various locations, among them Márquez, Los alumbrados, pp. 273-83; Alvaro Huerga, Historia de los alumbrados, Vol. V.

'La tendencia de los 'dejados' se caracteriza por una gran desconfianza hacia toda manifestación llamativa de amor divino. Las gracias sobrenaturales que una espiritualidad ambiciosa se complace en publicar, las tienen ellos por engaños del demonio, y aun sospechan que son pura comedia'. Bataillon, Erasmo y España, p. 171.

Alastair Hamilton, 'Merciful Inquisitors: Disagreements within the Holy Office about the Alumbrados of Toledo', in Querdenken: Dissens und Toleranz im Wandel der Geschichte: Festschrift zum 65. Geburtstag von Hans R. Guggisberg, (ed.) Hans R. Guggisberg and Michael Erbe (Mannheim: Palatium Verlag im J and J, 1996), pp. 123-33, esp. p. 128.

34 Quintín Aldea Vaquero, Tomás Marín Martínez and José Vives Gatell (coords.), Diccionario de historia eclesiástica de España (Madrid: CSIC, 1972-87), p. 1802; Diego Ignacio de Góngora, Historia del Colegio Mayor de Santo Tomás de Sevilla (Sevilla: E. Rasco, 189o), vol. 
respected theologian by 1527 when he was asked to provide his opinion on the early Alumbrados. He argued that not only should Alcaraz burn but also his accomplice Isabel de la Cruz since 'it would be great nonsense to condemn the disciple and save the teacher'. He continued by arguing that Gaspar de Bedoya deserved the same fate because of his fervor, which exceeded even that of his teachers, Alcaraz and De la Cruz. Ochoa went on to warn that unless this heretical spark was extinguished, Spain would be consumed by its fire. He claimed that the reach of this evil was already extensive and growing by the day and that like rotten meat it must be cut away to save the rest. ${ }^{35}$ Ultimately, however, the Consejo chose to handle the Toledo Alumbrados with leniency, prescribing public punishment and reclusion rather than flames. Although Ochoa's opinion was deemed excessively harsh in these cases, this did not prevent him from sharing what he knew and how he thought about Alumbrados and the dangers they posed in the future.

\section{Re-Defining Alumbradismo: Extremadura, 1570s}

Despite continuing suspicions that occasional individuals, mostly intellectuals and humanists, maintained a form of this heresy in the wake of the $15^{20}$, it was only in the 1570s that a group, this time in Extremadura, was identified as Alumbrados. ${ }^{36}$ However, the accused and their practices differed dramatically from their Toledo predecessors, and the Consejo elected to redefine the heresy in a new Edict of Faith that was released in 1574. By the time this group was punished in Extremadura, the definition of what it was to be an Alumbrado had evolved significantly.

The development of the meaning of Alumbradismo between the 1525 and 1574 Edicts of Faith reflected the changing preoccupations of the time. The culmination of the Council of Trent and nearly immediate acceptance of its precepts by Felipe II resulted in, at least in Spain, efforts at a Catholic Reformation intent on reaffirming the role and function of the institutional

2, pp. 46-50. There is another man by this name in the employ of the Inquisition as a fiscal in Cuenca and Seville before serving as inquisitor of Galicia between 1606 and 1611 . See Jaime Contreras, El Santo Oficio de la Inquisición de Galicia (poder, sociedad y cultura) (Madrid: Akal, 1982), p. 190, p. 323.

35 Archivo Histórico Nacional [AHN], Inquisición (all documents from this archive are from the Inquisition section unless otherwise specified), Leg. 106, Exp. 5, fol. 368.

On the influence of Erasmus on the early Alumbrados see Bataillon, Erasmo y España. 
Catholic Church. ${ }^{37}$ Of particular significance to the redefinition of Alumbradismo were the efforts to reform the clergy, encourage the laity to hear sermons and take communion more frequently, centralize and formalize the process of saint-making, and force beatas into convents. However, the zeal of the ecclesiastical hierarchy was not always effectively translated into more local settings. ${ }^{38}$ Despite how quickly and completely the mandates of the Council of Trent were or were not accepted locally, the impetus of the Tridentine decrees facilitated an expansion of the inquisitorial mandate. Originally established to police the habits and beliefs of New Christians, the efforts to homogenize Catholic practice provided the Inquisition with a forceful justification for the prosecution of Old Christian practices and beliefs that lay outside the bounds of the orthodoxy reaffirmed by Trent. ${ }^{39}$ The report of Dominican Alonso de la Fuente, which would eventually bring these latest Alumbrado suspects before the Holy Office, was steeped in rhetoric and examples of how this group failed to adhere to Tridentine ideals and thus warranted inquisitorial interest.

\section{The Crusader: Alonso de la Fuente}

The Dominican Alonso de la Fuente, who would bring the latest cases of Alumbradismo to the attention of the Consejo, was a native of Extremadura. He was born in Fuente del Maestre in 1533 to Old Christians with his father and grandfathers all members of the Military Order of Santiago. Sent to attend the Colegio de Santo Tomás in Seville, he took the Dominican habit in 1557 at the Real Convento de San Pablo in that same city. After over a decade at the Colegio,

37 Many historians prefer this term to 'Counter-Reformation' on the grounds that the Catholic Church did much more than react to the Protestant Reformation with Tridentine reforms. On this issue see John W. O'Malley, Trent and All That: Renaming Catholicism in the Early Modern Era (Cambridge: Harvard University Press, 2000).

38 There are numerous local studies on the effectiveness of Tridentine decrees in Spain. For a sampling see Henry Kamen, The Phoenix and the Flame: Catalonia and the Counter Reformation (New Haven: Yale University Press,1993); Sara T. Nalle, God in La Mancha: Religious Reform and the People of Cuenca, 1500-1650 (Baltimore: Johns Hopkins University Press, 1992); Allyson M. Poska, Regulating the People: The Catholic Reformation in Seventeenth-Century Spain (Leiden: Brill, 1998); Peter Burke, 'How to be a Counter-Reformation Saint', in Religion and Society in Early Modern Europe, 1500-180o, (ed.) Kaspar von Greyerz (London: German Historical Institute, 1984); Elizabeth A. Lehfeldt, 'Discipline, Vocation and Patronage: Spanish Religious Women in a Tridentine Microclimate', Sixteenth Century Journal, 30 (1999): pp. 1009-28.

Sarrión Mora, Beatas y endemoniadas, p. 180. 
first as a particularly talented student and later teacher, De la Fuente accepted a preaching position in Badajoz at the end of 1570 in his native Extremadura. ${ }^{40}$ His experiences in Seville at these renowned Dominican institutions would make him a particularly difficult voice to dismiss in the future when he began to claim that the Alumbrado heresy had infiltrated southern Spain. What we know about Alonso de la Fuente's role in pursuing Alumbrados - his discovery, ability to identify them, and his ensuing efforts to persecute them - are predominantly self-reported. The key document is his letter to King Felipe II in 1575, but its current whereabouts are unknown. Fortunately, it was transcribed in the early twentieth century although without reference to its location. Since then it has been copied, corrected, and the orthography modernized by Alvaro Huerga. ${ }^{41}$ Much of what is known about De la Fuente and his early crusade against Alumbrados comes from this document. ${ }^{42}$

According to De la Fuente, upon returning to Extremadura, he encountered a preacher with a company of beata followers. Although local opinion held the group in high esteem as pious and holy, De la Fuente became quickly disillusioned upon hearing that these beatas were experiencing ecstasies and raptures, especially after engaging in spiritual contemplation. De la Fuente ordered them to desist in the practice since, according to Catholic teaching, somatic experiences were meant to be the final step toward spiritual perfection rather than one of the first. His admonitions were met with ridicule and

\footnotetext{
$40 \quad$ Huerga, Historia de los alumbrados, Vol. I, pp. 49-55.

41 Huerga, 'Alonso de la Fuente, Carta y Memorial a Felipe II', in Historia de los alumbrados, vol. I, pp. 329-77. All citations to De la Fuente's report to Felipe II are from Huerga's transcription, cited hereafter as 'Carta y Memorial a Felipe II'. Huerga has reproduced many documents relating to cases of Alumbradismo in Extremadura, Cordoba and Mexico in the respective volumes of Historia de los alumbrados. The original archival citation, rather than Huerga, is provided if the researcher has confirmed the document's location and transcription.

42 Based on writings from De la Fuente, the Consejo, and the Llerena tribunal, it is clear that De la Fuente wrote with a zeal that matched his persecutory fervor. However, the documentation that remains of his crusade of the pen is limited, making his petition to Felipe II particularly important. Alvaro Huerga has attributed the enormously rich dossier found in AHN, Leg. 4443, exp. 24 to De la Fuente. However, upon consulting the original, nowhere on the document is there any clear indication of authorship by De la Fuente. The dossier seems to have been compiled in the seventeenth century (based on its archival location) to be consulted by the Consejo. Huerga discusses and acknowledges the difficulties of this document but maintains that it is the work of De la Fuente. Huerga, Historia de los alumbrados, vol. I, pp. 319-20, pp. 378-442.
} 
mocking. Undeterred, De la Fuente spent the next five years traveling and preaching against this genre of deviance all the while keeping the local inquisitorial tribunal in Llerena abreast of his discoveries. The tribunal, however, proved unresponsive, requiring De la Fuente to eventually address his concerns to the Consejo and even the king. Admitting that his reports contained 'things very new, very dark, and never seen by the Inquisition', his frustration at the indifference of the tribunal was palpable: 'I actually see the heresy clearly and openly, and I could not show it to the Holy Office nor find eyes able to see it'. Not only was the tribunal unconcerned, but his efforts to preach against these irregularities were often received with ambivalence, if not clear rejection. De la Fuente even began to suspect that individuals were reporting him to the Inquisition for causing scandal, although conceding that he 'never tired nor did the theme of Alumbrados ever leave my mouth'. ${ }^{43}$ His preaching, at least according to his own reporting, did convince a handful of individuals to abandon the heterodox group and return to the Catholic fold, and he utilized their knowledge and confessions to formulate more specific allegations against those who had previously been their co-religionists.

Based on De la Fuente's allegations it is clear that he was familiar with the 1525 Edict of Faith against Alumbrados but was in no way satisfied with its moderate assessment. While echoing certain concerns from that document, he drastically enhanced others. According to him this latest group believed that an individual could reach a point of spiritual perfection when virtuous works became unnecessary, as did obedience to prelates, the Pope, or the king because they were governed directly by God. They denigrated the sacraments of holy orders and marriage, even encouraging women not to participate, much less delight, in the fulfilment of the conjugal debt. Furthermore, they disparaged the need for fasts, claiming the superior efficacy of mental prayer and contemplation, which required them to eat well and not abstain from meat. Mental prayer was elevated to a sacrament and believed to be all that was necessary to comply with divine law. These Alumbrados advocated receiving communion in many forms so as to garner more grace. Nonetheless, averting one's eyes at the moment of the Host's consecration remained standard practice. Finally, there was no need to obey the Commandments to achieve salvation. ${ }^{44}$

At least part of what De la Fuente described resonated with the earlier understanding of Alumbrados. However, from this starting point he went on to

\footnotetext{
43 'Carta y Memorial a Felipe II', pp. 340-41, p. 351.

44 'Carta y Memorial a Felipe II', pp. 373-76.
} 
identify the dangerous threats posed by this type of spirituality and claimed that these alleged Alumbrados had fallen victim to the worst of them. His description was imbedded in contemporary understandings that perceived within the call for an increasingly interiorized spirituality the threat of demonic possession and sexual lasciviousness. ${ }^{45}$ De la Fuente accused members of this group of being witches (hechiceros) and practicing the magic arts (arte mágica). He claimed they were inspired by the demonic, alternatively describing what he uncovered as the work of Satan, the Antichrist, or demons. They invoked the Devil and made explicit pacts with him. ${ }^{46}$ Upon listing the 'Life and Errors of the Alumbrados', De la Fuente gave primacy to the proposition, 'They are great witches and magicians and they have a pact with the Devil. ${ }^{47}$ The close alliance between this doctrine and the Devil, according to De la Fuente, ultimately resulted in the Devil taking possession of these individuals, transforming them into endemoniadas. In this state, he claimed, the possessed members of the group would refuse communion at which time it would be administered to them forcibly so as to exorcise their demons. However, while conceding that a number of individuals had suffered sincere endemoniamientos, De la Fuente warned the Inquisition that some suspects may feign their possession by the Devil in an effort to dodge inquisitorial punishment. ${ }^{48}$ While the women involved in these raptures and ecstasies understood them as evidence of the divine, De la Fuente identified them as demonic in origin.

The demonization of liminal religious groups was a reoccurring theme in Western European thought. ${ }^{49}$ However, this demonization was often accompanied by efforts to sexualize such individuals by claiming they practiced all sorts of deviant erotic behaviors as well. Once he made clear the demonic nature of the group, De la Fuente went on to describe how this influence led to the indulgence of base carnal desires. He explained how many of the women involved 'were terribly inflamed with desires of the flesh', a problem for which their teachers provided the 'natural remedy' in the form of kissing these women's mouths, chest, and touching their 'shameful parts', claiming that such acts were not sinful because they were gifts of 'spiritual people'. These 'remedies' were frequent and advanced enough that steps were taken to ensure the

\footnotetext{
45 Sluhovsky, Believe Not Every Spirit, pp. 1-10.

46 'Carta y Memorial a Felipe II', pp. 333, 339, 340, 342, 348, 350, 354, 356, 36o, 365-69.

47 'Carta y Memorial a Felipe II', p. 373.

48 'Carta y Memorial a Felipe II', pp. 370-71.

49 Norman Cohn, Europe's Inner Demons: An Enquiry Inspired by the Great Witch-Hunt (New York: Basic Books, 1975).
} 
women did not conceive. Such flagrant sexual license, however, did not remain solely in the realm of mortals. De la Fuente reported that the Devil had sex with some of these women, occasionally appearing in the form of Christ crucified and causing them thousands of 'pollutions'. To hide their abominable acts, the teachers of the doctrine demanded a monopoly on their followers' confessions as well as their complete obedience, negating the need to follow the demands of other authority figures, whether ecclesiastical or familial.

To assure himself of the righteousness of his cause, De la Fuente chose to consult learned men in Seville, including the senior inquisitorial theologian maestro Juan de Ochoa, who had previously examined the Alumbrados of Toledo. These men all agreed that what De la Fuente described was a serious matter, but it was Ochoa who explained to him that what he presented was 'a portrait of what the Alumbrados of Toledo taught'.50 Having earlier provided his opinion that the first Alumbrados should burn for their heretical crimes, Ochoa was in a position to not only enlighten De la Fuente about the type of heresy he had uncovered but also to share his vitriol towards this group. Although the Consejo failed to punish the Toledo Alumbrados according to Ochoa's suggestion, this did not dampen his reputation or prevent the Inquisition from consulting him on serious theological issues later. He participated in the trial of the Spanish humanist Juan de Vergara, and despite already being in his seventies Ochoa was part of the Spanish contingent sent to Rome during the trial of Bartolomé de Carranza, where he would die in $1574 .^{51}$ Whether De la Fuente had previously recognized the resemblance between what he encountered in Extremadura and the earlier Alumbrados of Toledo is unclear. However, in the following years, he readily accepted and proclaimed this similarity. Available documents indicate that at least by the beginning of 1573 De la Fuente was calling the individuals he uncovered Alumbrados.

\section{A New Definition of an Old Category: 1574 Edict of Faith}

The Consejo finally dispatched orders to send all of the papers relating to these alleged Alumbrados cases in Extremadura to Madrid after one of their own, Rodrigo de Castro, was personally approached by De la Fuente and presented with yet another of his reports. Castro would sign each of the ensuing

$50 \quad$ 'Carta y Memorial a Felipe II', p. 340.

51 Vicente Beltrán de Heredia, Miscelánea Beltrán de Heredia. Colección de artículos sobre historia de la teología española (Salamanca: Editorial OPE, 1972), vol. 2, pp. 480, 491, 493; vol. 4, pp. 372-73. 
directives regarding the transmission of these materials from Llerena to the Consejo. In short order, the papers arrived and the Consejo ordered the tribunal to take action against 'those that they call Alumbrados.' ${ }^{52}$ Nonetheless, De la Fuente remained unsatisfied. He wrote directly to yet another member of the Consejo, Martín de Salvatierra, and this letter was dispatched to the Llerena tribunal by August of 1573 to be taken into consideration as they investigated the cases. ${ }^{53}$ De la Fuente continued to address members of the Consejo directly and he wrote personally to the newly appointed Inquisitor General, Gaspar de Quiroga, in early $1574 .{ }^{54}$ His earlier communication with Castro resulted in the dispatch of papers from Llerena to the Consejo, and his letter to Salvatierra had been sent to Llerena as a tool to be used in the investigation. His contact with the Inquisitor General resulted in orders that he personally appear before the Consejo in Madrid. ${ }^{55}$ When asked his opinion of the ongoing cases, De la Fuente denounced the incompetence of the Llerena tribunal, claiming its members lacked the theological capacity necessary to comprehend 'such subtle and hidden' matters. ${ }^{56}$ De la Fuente suggested an inquisitorial inspection, or visita, be conducted and recommended Juan López de Montoya be appointed to the task. The Consejo consented. López de Montoya was promoted to inquisitor, dispatched to Extremadura laden with De la Fuente's writings, and ordered to consult with De la Fuente during his 'visita of the alumbrados'.57 Although he struggled to gain the ear of the Llerena tribunal, the Consejo proved significantly more amenable to De la Fuente's concerns as well as suggestions.

In preparation for his task, López de Montoya was armed with a revised Edict of Faith defining the heresy of Alumbradismo, which clearly demonstrated the influence of De la Fuente's opinion on how it was understood. ${ }^{58}$ A number of key doctrinal points from the Edict of 1525 reappeared in the 1574 Edict, especially those repeated by De la Fuente in his reports. These included the preference for mental over vocal prayer, speaking ill of religious orders and their members, and rejecting the need for corporeal manifestations of faith, the adoration of images, and hearing sermons. Augmenting the latest Edict

$5^{2} \quad$ AHN, book 578 , fols. 82v, 86r-v, 91v, $101 \mathrm{v}$.

53 AHN, book 578, fol. 107v.

54 'Carta y Memorial a Felipe II', p. 360.

55 AHN, book 578, fol. 182r.

56 'Carta y Memorial a Felipe II', p. 362.

57 AHN, Leg. 4573, caja 3, pliego 11.

58 AHN, book 578, fols. 186v-187r; AHN, Leg. 4573, caja 3. 
were demands for obedience to the teachers of the doctrine and rejection of any authority that interfered with their mental prayer. This included an increasingly exclusive idea that the only means to salvation was through the teachings of these same Alumbrados. The importance of communion as a means to experience the divine was emphasized while at the same time devaluing the necessity of its consecration. Most divergent from the earliest Edict, and also the earliest accused Alumbrados, was the addition of a clause that certain fervors, tremors, pains, shaking and fainting spells were indications of God's love and demonstrated the presence of the Holy Spirit in the individual. ${ }^{59}$ It had been De la Fuente who had first brought these somatic experiences of the Extremadura group to the Consejo's attention. Therefore it is clear that at least some of his allegations found their way into the revised Edict of 1574 sent with López de Montoya on his investigations in Extremadura.

Despite the visible influence of De la Fuente's reports in the construction of the new Edict of Faith, the Consejo was not wholly convinced by his polemics, especially in relation to who constituted the Alumbrado menace. In his report to Felipe II De la Fuente implicated the Jesuit Order, which he regularly referred to as 'teatinos' in the heresy of Alumbradismo. ${ }^{60} \mathrm{He}$ also echoed the concern about the presence of reformed Franciscans, which had been present since the earliest cases in the $1520 .{ }^{61}$ While the reference to the Franciscans had clear precedents, it was De la Fuente's concern over the Jesuits that signified the future trajectory of the allegation despite its lack of originality. The distinguished Dominican theologian Melchor Cano had identified connections between alumbrados and Jesuits immediately following his participation in the Council of Trent. ${ }^{62}$ The founder of the Company of Jesus, Ignatius Loyola,

59 In fact, such exterior manifestations would have appalled the Alumbrados of Toledo. Bataillon, Erasmo y España, pp. 170-71.

60 De la Fuente repeatedly refers to the 'teatinos' in connection with Alumbrados, 'Carta y Memorial a Felipe II', pp. 339, 344, 355, 372, 376. De la Fuente makes the connection between his use of 'teatino' and Jesuits explicit in the report he submitted to Cardinal Infante Don Enrique in Portugal: 'Memorial en que se contiene la herejía y engaño sutilísimo que enseñan los Alumbrados de Castilla y es doctrina que mana de los Teatinos, que por otro nombre se llaman de la Compañía de Jesús'; Huerga, Historia de los alumbrados, vol. I, p. 452.

61 'Carta y Memorial a Felipe II', pp. 349-50.

62 Melquiades Andrés Martín, El misterio de los alumbrados de Toledo, desvelado por sus contemporáneos (1523-1560) (Burgos: Aldecoa, 1976), pp. 33-37; Sluhovsky, Believe Not Every Spirit, pp. 108-09. 
was in fact repeatedly questioned by the Inquisition on suspicions of Alumbradismo. Additionally, concerns that Loyola's Spiritual Exercises led people away from orthodoxy proved a reoccurring anxiety throughout the sixteenth century. Despite De la Fuente's equation of Jesuits and Alumbradismo, the Consejo failed to codify any such connection in the new Edict of Faith. ${ }^{63}$ Nonetheless, in the future an increasing number of Jesuits, those practicing forms of spirituality reminiscent of the Jesuits, and those with Jesuit confessors, would find themselves before the Inquisition accused as Alumbrados, a phenomena foretold by De la Fuente.

De la Fuente also referred to the notion of an Alumbrado-Converso nexus originally posited during the Toledo cases earlier in the century. He reported that the entire population of the town of Zafra was Converso and that every one of them were Alumbrados, or at the very least relatives and friends of Alumbrados. He went on to claim that in that town sixty of the seventy priests were in fact Jews. ${ }^{64}$ Of the nineteen individuals who would eventually be punished as Alumbrados in the upcoming auto, nine were either vecinos or naturales of Zafra. Nonetheless, not one of these individuals was identified as a Converso in the report of the auto de fe. ${ }^{65}$ Therefore this preponderance of suspects from Zafra was, in all likelihood, more related to the town being one of the first locations visited by Inquisitor López de Montoya rather than any sort of continuing understanding about the entanglement between Alumbrados and Conversos. Ultimately, De la Fuente's efforts to associate these two groups in his petition to the king were half-hearted at best. ${ }^{66} \mathrm{He}$ demonstrated a significantly greater concern about the possibility of a Jesuit infused spirituality and the participation of the Devil rather than any remnants of Jewish practice or belief. Although De la Fuente proves that the concept of an AlumbradoConverso nexus had not been forgotten, it held significantly less traction in a post-Tridentine religious landscape than it had in the decades following the expulsion and mass conversion of the Jews.

If the Consejo ignored De la Fuente's concerns about Alumbrados as either Jesuits or Conversos, they also failed to adopt his concerns about particular

63 For an overview of Loyola's interactions with the Inquisition see Huerga, Historia de los alumbrados, vol. v, pp. 221-36. See also Ignacio Cacho Nazábal, Iñigo de Loyola el heterodoxo (San Sebastián: Universidad de Deusto, 2006).

64 'Carta y Memorial a Felipe II', pp. 342, 363.

65 AHN, Leg. 1988, exp. 12.

66 'Carta y Memorial a Felipe II', pp. 363-66; Huerga, Historia de los alumbrados, vol. I, pp. $145^{-47}$. 
Alumbrado practices and beliefs. Alison Weber has best summed up these rejected points as De la Fuente's 'eroto-demonic theory of heresy'.67 Despite the immense effort De la Fuente put into both demonizing and sexualizing those he called Alumbrados when writing to Felipe II, the new Edict never mentioned the Devil or any form of sexual misconduct. Although the Edict pre-dated De la Fuente's report to the king, it obviously failed to rein in his most exaggerated claims. Nonetheless, even De la Fuente's more dramatic concerns would find a certain measure of vindication in later years.

According to De la Fuente, the freshly appointed inquisitor to Extremadura, López de Montoya, struggled to determine whether the alleged Alumbrados' inspiration was holy or demonic. Acting as informal consultant, De la Fuente insisted that if the lives of these suspects were taken into account, not just their claims but their manner of living, the origin of their beliefs would become clear. This advice and the ensuing investigation into the habits of the Alumbrados, proved sufficient to convince López de Montoya of their deviance. ${ }^{68}$ The advice to judge the heterodoxy of suspected Alumbrados based on their lifestyle would become a regular directive in later persecutions of Alumbrados but also spiritual women in general. ${ }^{69}$ In fact, De la Fuente and his advice were judged useful enough for the Consejo to promote him to a salaried member of the inquisitorial staff. Henceforth he was paid to accompany López de Montoya on his visita. ${ }^{70}$

\section{New Men, New Instructions, a New Auto de Fe}

The growing number of suspects generated by the work of López de Montoya and De la Fuente convinced the Consejo that the Llerena tribunal needed additional personnel. The inquisitor of Toledo, Antonio Matos de Noroña was sent 'to find out the truth of the said matter of the Alumbrados'. Upon his arrival, the newest appointee delved into the mass of already accumulated documentation regarding the alleged Alumbrados, and the Consejo granted him permission to appoint theologians to assess the suspects. De la Fuente, López de Montoya, and Matos de Noroña, formed an inquisitorial cadre whose mission was to root out the heresy of Alumbradismo from Extremadura. These

\footnotetext{
67 Alison Weber, 'Demonizing Ecstasy', pp. 141-58, esp. p. 153.

68 'Carta y Memorial a Felipe II', pp. 367-69.

69 Sluhovsky, Believe Not Every Spirit, pp. 197, 204-05.

70 His salary consisted of three and a half reales a day. AHN, book 578, fols. 274r-v, 301v, 304r, 322 r.
} 
men would become the experts on this heresy as they worked to eradicate it. In the process, all of their careers benefited, each earning promotions for their diligent work in identifying and helping to stamp out Alumbradismo.

In 1578 the concerns of De la Fuente that had been dismissed in the 1574 Edict were partially addressed. As investigations continued, the accuracy of De la Fuente's allegations about the group's sexual practices became clear. The Consejo released a carta acordada in January 1578 demanding the following clause be added to the 1574 Edict of Faith: 'If they know that between the said Alumbrados and their devout daughters of confession and communion that certain touching of kisses and embraces and other dishonesties occurred, saying that they give it and the women receive these for consolation, strength and inspiration to maintain them in the prayer and meditation that they teach. ${ }^{71}$ This was the first time Alumbrados were officially charged with any form of sexual depravity, an indictment absent from both the 1525 and 1574 Edicts. Although De la Fuente made it clear from the beginning that this was inherent to the Extremadura group, the Consejo only conceded the point after an additional four years of investigation and interrogation.

Finally on 14 June 1579 the Llerena tribunal conducted a public auto de fe in which nineteen individuals were punished 'for the sect and doctrine of Alumbrados'. All were forced to abjure de levi with six religious men sentenced to the galleys, one of the harshest punishments in the Inquisition's repertoire short of death. All of the men accused ultimately confessed to indulging in various forms of sexual license with their female penitents. Some admitted, including those subjected to torture, to teaching 'Alumbrado doctrines' but failed to specify what exactly this entailed. ${ }^{72}$ The beatas who were punished received one hundred lashes and were required to spend three years in reclusion and were henceforth assigned confessors. Some of the beatas also faced fines ranging from 30,000-50,000 maravedís. This auto de fe made it clear that by 1579 De la Fuente's allegations of sexual misconduct had been validated. Although the Edict of Faith of 1574 made no mention of such misbehavior, the 1578 carta acordada remedied this omission, and by 1579 the erotic characteristics of the heresy were formally acknowledged to the public in the auto defe. ${ }^{73}$

\footnotetext{
$71 \quad$ AHN, book 579, fol. 122.

72 AHN, Leg. 1988, exp. 12.

73 It is important to remember that 'We cannot prove with certainty that the "fondling" that the Llerena Alumbrados confessed to never took place. But before we accept that the
} 


\section{Deploying Alumbradismo: Spain}

The Alumbrados of Extremadura failed to embody the most radical of De la Fuente's accusations, but the appearance of a group of alleged Alumbrados in Cordoba a short while later provided the Inquisition with an opportunity to reassess his claims. De la Fuente had alerted the Consejo to suspected Alumbrados in Jaén as early as 1574, before the Extremadura cases concluded, but only in 1586 would the Consejo dispatch Juan López de Montoya to investigate the heretical threat. ${ }^{74}$ The most experienced vistador on the matter of Alumbrados, López de Montoya's earlier work persecuting and punishing Alumbrados in Extremadura could only be a boon for the Cordoba tribunal confronting its first cases of this heresy.

For this visita López de Montoya was instructed not to involve his old colleague De la Fuente in the investigation. ${ }^{75}$ By this time the anti-Alumbrado crusade of De la Fuente had taken him to Lisbon, where he blatantly accused the Jesuit order of participating in the heresy. This escapade landed De la Fuente briefly in the inquisitorial jails of Seville and required no small amount of diplomacy to resolve. ${ }^{76}$ This was neither the first nor the last time that De la Fuente would implicate the Jesuit order in the heresy of Alumbradismo, however, his allegation failed to resonate with the Inquisition in Portugal. Refusing to be silenced, De la Fuente wrote directly to his other former colleague from the Alumbrado persecution in Extremadura, Antonio Matos de Noroña, who had since been promoted to a seat on the Consejo. ${ }^{77}$ De la Fuente's earlier efforts directed at particular members of this body had borne fruit for his cause and there was no reason to believe that this time would be any different. De la Fuente reminded Matos de Noroña that he had already denounced Alumbrados

Alumbrados were indeed an orgiastic sect, we must remind ourselves that charges of sexual deviance are a common and effective stratagem in narratives of persecution; denunciations were made under the duress of an Edicto de fe; and the Alumbrados, many aged and ill, confessed after long periods of imprisonment and after being subjected to torture'. Weber, 'The Inquisitor', p. 189.

AHN, book 581, fols. 30v-31; AHN, Leg. 2394 s.f. Previous investigations had been made in Baeza, also in the jurisdiction of Cordoba, see Huerga, Historia de los alumbrados, Vol. II, pp. 97-126, 143-74.

75 By this time De la Fuente was a prior in Úbeda; AHN, book 581, fol. 58 .

76 For more on the 'Portuguese Adventure' of De la Fuente, see Huerga, Historia de los alumbrados, Vol. I, pp. 160-223.

AHN, book 578, fols. 304r, 306r, $307 \mathrm{v}$. 
in Jaén, and that recently his suspicions had only been confirmed: 'It is important for the service of God that the gentlemen [of the Consejo] understand that the suspicions of the sect of Alumbrados are true and that they are in the Kingdom and particularly in the bishopric of Jaén. ${ }^{78}$ A short while later, De la Fuente was ordered to appear yet again before the Consejo and he used this opportunity to deliver additional reports about the Alumbrado threat in Cordoba. ${ }^{79}$

López de Montoya continued his visita without the assistance of De la Fuente, and his report is the most detailed existing document about the Alumbrados of Jaén. ${ }^{80}$ However, because his job consisted only of gathering testimony, a process that lacked the safeguards of an inquisitorial trial defense attorney, character witnesses, and the ability to respond to accusations - the report provides only the darkest possible portrait of this group. ${ }^{81}$ The multifarious accusations against the supposed leader Gaspar Lucas included sexual misconduct, crimes against the sacraments of confession and communion, as well as claims that he could discern and dispel evil spirits, all in association with his devoted beata followers. He regularly engaged in sexual acts with his beatas, both inside and outside of the confessional, including kissing, embracing, and fondling while discussing 'the spirit of fornication'. He demanded a monopoly on his beatas, confessions and obedience, while assuring them that they could not sin without the intent to sin. His beatas were known for taking daily communion at his encouragement, often without previously confessing. It was typically during communion that these women would fall into fits, throwing their arms up, screaming, howling, gritting their teeth, and sometimes even fleeing the church. In such moments, despite these defiant actions, Lucas would pry their mouths open and forcibly administer the sacrament of communion to cure these women of what they claimed was proof of their endemoniamientos. Triumphing over the Devil was a common hagiographical trope and was understood to be part of the process toward union with the Divine. In this case, the beatas hoped that by demonstrating their triumph over the demonic within them, with the help of their confessor, that they were proving themselves as holy women. ${ }^{82}$ Not surprisingly,

\footnotetext{
78 AHN, Leg. 2394 s.f. Letter from Alonso de la Fuente a Don Antonio Matos de Noroña.

79 AHN, book 581, fol. 71; AHN, Leg. 2394 s.f.; Huerga, Historia de los alumbrados, Vol. II, p. 241

80 Their procesos no longer exist.

81 Weber, 'The Inquisitor', p. 189.

82 José Luis Sánchez Lora, 'Demonios y santos: el combate singular', in El diablo en la edad
} 
testimony abounded against Lucas' followers as well. They experienced and publicized visions, revelations, raptures, clairvoyance, and ecstasies, which most witnesses claimed, at least to the visitador, were feigned to convince their audience of their holiness and thus garner material rewards. Eventually a number of the accused beatas would confess to simulating their supposed gifts, and some would even testify against Lucas. By the conclusion of what was already an extensive report, López de Montoya stated: 'Many other things I have received in this visita against other beatas and individuals given to these exercises, that, to relieve the long-windedness, will not be included'. Apparently there was no lack of witnesses. ${ }^{83}$

\section{Another Auto de Fe, Another Appraisal}

The auto de fe held in Cordoba on 21 January 1590 punished eight individuals 'for the sect of Alumbrados and feigning raptures and demonic possession', ${ }^{84}$ The leader Lucas was charged with taking sexual license with his beatas and encouraging them to regularly partake of communion, frequently causing scandal when the beatas fell into various states of supposed rapture. The tribunal found him guilty of knowing and consenting to the beatas' counterfeit behavior and then supporting their claims that they were endemoniadas. Denying everything initially, his will softened after torture, and he admitted to inappropriately touching these women and then vaguely to 'having treated the doctrines of which he was accused'. The fact that this statement was elicited only in the wake of torture begs the question of what Lucas even understood about the heresy he confessed to teaching and spreading. Although Lucas was clearly identified in the report of the auto de fe as a Converso, he was the only one among the suspects punished as Alumbrados. The foremost beata of the group, María Romera, faced charges for acting as Lucas' concubine and eventually confessed to feigning raptures, revelations, and visions in an effort

moderna, (eds.) María Tausiet and James S. Amelang (Madrid: Marcial Pons, 2004), p. 176; Sluhovsky, Believe Not Every Spirit, p. 27; Sarrión Mora, Beatas y endemoniadas.

AHN, Leg. 1856 s.f., 'Relación de la visita que se hizo en la ciudad de Jaén y los lugares de su comarca por la Inquisición de Córdoba en 1586'. Also transcribed in Huerga, Historia de los alumbrados, Vol. II, pp. 540-614.

84 The report of the 1590 auto de fe in Cordoba can be found at AHN, Leg. 1856/1, s.f. For a full transcription of the 'Relación' of the 159 a auto, see Rafael Gracia Boix, Autos de fey causas de la Inquisición en Córdoba (Cordoba: Diputación Provincial, 1983), pp. 224-47. Huerga has transcribed the portion of the report pertaining to alumbrados. Huerga, Historia de los alumbrados, Vol. II, pp. 617-24. For a discussion on how anxieties about feigned possessions became legal categories see Sluhovsky, Believe Not Every Spirit, pp. 188-97. 
to be taken as saintly or, alternatively, as possessed by the Devil, although she was sure to clarify that she had never made a pact with him. The rest of the accused were sentenced as accomplices and often imitators of the deceits of Lucas and Romera. Most of the accused eventually confessed to simulating their demonstrations of sanctity and demonic possession, some under torture, some freely.

If the Inquisition originally dismissed De la Fuente's 'eroto-demonic theory of heresy' in relation to the cases in Extremadura, the cases in Cordoba required a re-evaluation of his claim. By 1590 the Inquisition had clearly come to appreciate the sensual characteristics of the Alumbrado heresy, as posited by De la Fuente, however, the Cordoba group forced them to reconsider the role of the demonic. However, just as De la Fuente had predicted in his reports about Extremadura, in Cordoba the defendants ultimately chose to confess to feigning their demonic possessions rather than risk the consequence for being truly possessed by the Devil. Had the accused not confessed to faking their possessions, perhaps other aspects of De la Fuente's 'eroto-demonic theory of heresy' would have proven more influential. However, with these confessions, the tribunal had no need to inquire further into the role of the Devil among these Alumbrados. In Cordoba the guilty were punished not only as Alumbrados but also for 'feigning raptures and demonic possession', a designation dramatically different from categories assigned to earlier Alumbrados and which acknowledged the duplicity of their alleged possessions. Although the Consejo failed to accept De la Fuente's idea that the Devil lurked in Alumbrado shadows, it was willing to concede that at least some Alumbrados pretended that was the case.

In many ways, the Alumbrados of Cordoba more closely resembled the heresy outlined by De la Fuente than those he intended to describe from Extremadura. This was the product of a laity primed to denounce and the deployment of inquisitorial expertise, both possible due to the temporal and geographic proximity of the two outbreaks. De la Fuente had proudly admitted to undertaking a five year preaching campaign against Alumbrados anywhere and everywhere he could since he first discovered them in 1570 . His campaign was so persistent and stubborn that some considered him deranged, and he feared others denounced him to the Inquisition for causing scandal. Although often encountering ambivalence, occasionally De la Fuente was confronted with outright hostility. In one instance, a beata stormed the pulpit following his sermon, brandishing a cross and decrying everything he had said before she was forcibly removed. Other times he would be met with counter-sermons against his message. De la Fuente was even ordered to cease preaching at one point because of the uproar he caused. This extensive and even dramatic 
preaching campaign would have exposed a wide audience to De la Fuente's infamous topic, Alumbrados, influencing the laity's understanding of what this heresy entailed, who could be charged with it, and who and what they should denounce. ${ }^{85}$ By this time the laity would also have been exposed to the heresy of Alumbradismo through its punishment at the auto de fe of 1579. The most potent aspect of this event as a public spectacle was not learning how to be orthodox, but rather how to identify heterodoxy. The auto would have directly informed those present about the heresy of Alumbradismo while also stimulating discussion that would reach further and last longer than the event itself. $^{86}$ It is difficult to imagine that an adjacent inquisitorial jurisdiction would not have heard reports, or at the very least rumors, about an auto de fe and extensive preaching campaign. As the inquisitor Salazar de Frías pointed out about charges of witchcraft in 1612, 'There were neither witches nor bewitched until they were talked and written about'; the same thing seems to be true of Alumbrados. ${ }^{87}$ The laity in Cordoba was primed, by De la Fuente's preaching campaign and the recent punishment of Alumbrados to identify and denounce en masse, at least according to the report of López de Montoya, suspect behaviors related to this heresy when an inquisitorial visitador came to town. 88

Without the laity the Inquisition was incapable of functioning and pursuing suspects. ${ }^{89}$ However, once the laity provided denunciations the inquisitorial machine was set in motion. The deployment of a cadre of inquisitorial personnel

85 'It is hardly possible to exaggerate the importance of evangelism in the dissemination of ideas, and of the itinerant preacher, the archetypical outsider, in prompting the questioning of habits of life and deference long accepted as simply how things are'. Moore, The War on Heresy, p. 322.

86 Vincent Parello, 'Inquisition and Crypto-Judaism: The 'Complicity' of the Mora Family of Quintanar de la Orden', in Conversos and Moriscos in Late Medieval Spain and Beyond, I: Departures and Changes, (ed.) Kevin Ingram (Leiden: Brill, 2009). Another example of the dissemination of a heretical discourse amongst a laity through inquisitorial procedure is the case of the benandanti, see Ginzburg, The Night Battles.

87 Henningsen, The Witches' Advocate. See also Michel de Certeau, The Possession at Loudon (Chicago: University of Chicago Press, 200o).

88 Elia Nathan Bravo, 'La Inquisición como generadora y trasmisora de ideologías', p. 276. I appreciate Carlos Cañete taking the time to challenge me to consider the ramifications of orality and oral transmission.

89 There are a number of studies demonstrating this point. In particular see Bartolomé Bennassar, 'Patterns of the Inquisitorial Mind as the Basis for a Pedagogy of Fear', in The Spanish Inquisition and the Inquisitorial Mind, (ed.) Ángel Alcalá (Boulder: Social Science Monographs, 1987), pp. 177-84; and Werner Thomas, Los protestantes y la Inquisición en 
who had worked together to identify, define, and prosecute Alumbrados in Extremadura helped ensure that the persecution of this heresy in Cordoba closely resembled that precedent. De la Fuente, López de Montoya, and to a lesser degree Matos de Noroña, based their work in Cordoba on their recent experiences in Extremadura. It is therefore not surprising that the Cordoba group of Alumbrados closely resembled those of Extremadura. Both groups were prosecuted under the terms of the same Edict of Faith by men who had all profited professionally from their work discerning and extirpating this heresy previously and who were, therefore, convinced of its existence and the dangers it posed: 'It is entirely to be expected that once the authorities began to look for heretics they would have no difficulty finding them: ${ }^{90}$ Furthermore, in the wake of Extremadura, both the local tribunals and the Supreme Council of the Inquisition increasingly accepted at least certain aspects of the theory of Alumbrados originally posited by De la Fuente. Although the Inquisition failed to incorporate the most radical of his tenets into the 1574 Edict of Faith, the ensuing carta acordada of 1578 , auto de fe of 1579, and finally the auto of 1590, demonstrated a marked and increasing acceptance of at least some of De la Fuente's ideas.

\section{Deploying Alumbradismo: New Spain}

De la Fuente's contributions to the redefinition of Alumbradismo extended beyond the Iberian Peninsula. The release of the 1574 Edict of Faith, including his input, was quickly followed by its dispatch to each of the local inquisitorial tribunals, including the one recently founded in New Spain. Rather than release a special Edict of Faith solely addressing Alumbrados, the tribunal of New Spain incorporated this material into its General Edict of Faith. ${ }^{91}$ However, just as the carta acordada of 1578 failed to be integrated into the sixteenth century General Edicts of Faith against Alumbrados in Spain, it similarly failed to

España en tiempos de Reforma y Contrarreforma (Leuven: University of Leuven Press, 2001).

$90 \quad$ Moore, War on Heresy, p. 296. See also Lerner, Heresy of the Free Spirit, p. 125: 'since Inquisitors were commissioned to look specifically for heretical beghards and beguines they usually managed to find them. At least they maintained that they did'.

91 Archivo General de la Nación (Mexico) [AGN], Inquisición, Vol. 1481, fols. 121v-125r; Vol. 1511, fols. 14-19; Vol. 1564, exp. 31, fols. 1-3v. All documents from this archive are from the Inquisition section. Museo Nacional de Antropología (Mexico City), Colección Antigua, 341, fols.1-8v. 
find a place in New Spain's General Edicts. ${ }^{92}$ Nonetheless, the mere existence of propositions about Alumbrados, according to current inquisitorial understandings of the heresy, did not produce denunciations. Although readily available within the inquisitorial catalogue of heresies and regularly presented to the public alongside other heresies, the charge of Alumbradismo remained unused for nearly two decades.

\section{A New Crusader?: Dionisio Castro}

The Dominican Dionisio Castro presented the first denunciation against Alumbrados in New Spain in 1593. The General Edict of Faith had been read aloud in Mexico City on 14 March and was, in all likelihood, a catalyst for Castro's denunciation, which was being forwarded to the tribunal of New Spain by 1 April..$^{93}$ In this document Castro explained why he decided to denounce these particular individuals after hearing about their teachings: 'not feeling good about this language, because it smells and seems a lot like the Alumbrados that existed in Spain in the land of Extremadura, against whom I preached and was present for their imprisonment and punishment. ${ }^{94}$ Clearly, this meant that Castro was familiar with the work of De la Fuente, as the driving force behind the investigation and persecution of Alumbrados in Extremadura. However, one historian has gone so far as to claim that Castro was De la Fuente's protégé. ${ }^{55}$ Although difficult to prove, there is plenty of circumstantial evidence that attests to this possibility. Castro was also a native of Extremadura, twelve years De la Fuente's junior, who would follow in his footsteps, taking the Dominican habit at San Pablo and attending the Colegio de Santo Tomás in Seville. ${ }^{96}$ Despite whether or not these men personally knew each other, the Dominicans of Seville clearly provided them with a shared intellectual and spiritual formation.

Castro's denunciation of Alumbrados in New Spain conformed to the 1574 Edict of Faith, including its remnants from the 1525 Edict. He explained how the male leaders of this group, specifically the chaplain of a local convent in Puebla, Juan Plata, and his assistant, Alonso de Espinosa, advocated for an

\footnotetext{
92 The carta acordada was clearly received and was listed in a 1711 compilation of instructions and similar orders. AGN, Leg. 1481, fols. $157 \mathrm{~V}-158 \mathrm{r}$.

93 AGN, Vol. 1564, exp. 31, fols. 7v.

94 AGN, Vol. 180, exp. 1, fols. 10.

95 Jaffary, False Mystics, p. 32.

96 AGN, Vol. 180, 1, fols. 10r-15v. Castro was born approximately in 1545 based on the author's calculations. See also Julio Jiménez Rueda, Herejías y supersticiones en la Nueva España. Los heterodoxos en México (Mexico: Imprenta Universitaria, 1946), pp. 139-56.
} 
interior and antinomian spirituality unencumbered by exterior demonstrations of faith. They rejected the rites of confession and communion claiming that these could be done spiritually without the need for intermediaries or even the body. They discouraged the taking of holy orders as well as the use of rosaries and images believing all of these only shackled individuals to the world of the profane. These characteristics, originally posited in the 1525 Edict of Faith, had survived the redefinition of the heresy in 1574 and remained part of the inquisitorial understanding of Alumbradismo. ${ }^{97}$

Castro, however, also referenced a number of behaviors that made his familiarity with the more novel understandings of Alumbrados formulated in Extremadura clear. He repeatedly discussed the scandal caused by the leaders of this group within the convent they oversaw. Their favouritism toward certain nuns, especially Agustina de Santa Clara, whom they alleged was particularly saintly, resulted in rumors that this partiality had descended into the fulfillment of more base desires. Castro further recounted rumors that these men embraced and fondled the nuns in their care. When Plata was questioned about such actions, he claimed no sin had been committed since it had all been done with good intent and not with the will to sin, and he assured skeptics that his interactions with the nuns were dictated by godly revelation. Such behaviors were more reminiscent of the Alumbrados of Extremadura than their earlier precedents in Toledo. 98

Despite Castro's role initiating investigations against alleged Alumbrados in New Spain he was never an adamant anti-alumbrado crusader in the model of De la Fuente. Nonetheless, his denunciation provided the tribunal with a starting point from which it could assume its own investigative impetus. Eventually the majority of these suspects would be arrested for 'following and approving of the sect of Alumbrados. ${ }^{99}$ However, the Inquisition's investigations did not always result in the expansion of initial allegations. ${ }^{100}$ At times the investigative procedures of the tribunal allowed it to act as a mitigating force in heresy accusations, and this was the case for Alumbradismo in New Spain. ${ }^{101}$

\footnotetext{
97 AGN, Vol. 180, exp. 1, fols. 10-15, 17-18.

98 AGN, Vol. 180, exp. 1, fols. 10-15, 17-18.

99 AGN, Vol. 209, exp. 6, fol. 131; Vol. 180, fol. 1v; Vol. 210, exp. 2, fol. 62v.

100 For a discussions of how this process functioned see Ginzburg, The Night Battles; Arnold, Inquisition and Power; Given, Inquisition and Medieval Society, among others.

101 The Spanish Inquisition is best known for acting as a moderating force in the face of allegations of witchcraft. See Henningsen, The Witches' Advocate.
} 
The supposed Alumbrados of New Spain shared similarities with those accused in Extremadura but also with those in Cordoba, although how much the tribunal of New Spain would have known about the latter considering their very recent punishment is questionable. Alonso de la Fuente would have easily recognized the suspects in New Spain as Alumbrados, especially considering their rampant sexual misconduct. ${ }^{102}$ These individuals also attempted to convince others that they were saintly through the use of prognostication and claiming that they could see, and even assist, souls in purgatory. One beata was infamous for her very public displays of what she claimed were divine ecstasies and raptures, even going so far to demonstrate these before the inquisitors while she was being interrogated. ${ }^{103}$ Although in Cordoba beatas had feigned demonic possession to demonstrate their ability to overcome this well-known obstacle on the path to saintliness, in New Spain these women chose to feign sanctity by explaining their somatic experiences as blessings directly from God. De la Fuente would have recognized in these suspects of New Spain many of the traits he posited about the Alumbrados of Extremadura.

\section{Investigation and Inquiry}

During the trials of the suspects in New Spain there were numerous reasons and opportunities to identify them as Alumbrados. The initial denunciation of Castro labeled them as Alumbrados. The tribunal's prosecutor ordered their arrest 'for following and approving of the sect of Alumbrados'. The most damning of the theological assessments indicted the beliefs of one suspect as reflecting 'content that seems to be of the Alumbrado dogmatists of Llerena'.104 Another calificador suggested that this group's rejection of exterior acts of faith was 'suspected of the doctrine of alumbrados'.105 A plethora of other assessments included various forms of the word 'alumbrar', from which the label 'Alumbrado' stemmed but without necessarily or explicitly linking these to the charge of heresy. Individuals were described variously as 'suspected of alumbramiento,'106 demonstrating 'indicationsofalumbramientoandillusion'107

\footnotetext{
102 The details of these deeds litter the case files of Juan Plata, Agustina de Santa Clara and Marina de San Miguel. AGN, Vol. 180, exp. 1- 2; Vol. 210, exp. 3.

103 Evidence of such behavior can be found throughout the proceso of Marina de San Miguel, AGN, Vol. 210, exp. 3. See Holler, 'More Sins than the Queen of England', pp. 216-20. 
or 'alumbramientos, illusions, and deceits' ${ }^{108}$ Nonetheless, by the time of the prosecutor's formal accusation and the presentation of these subjects in the public auto de fe in 1601, there was no mention of the heresy of Alumbradismo. The guilty were punished instead for 'diverse crimes' and for participating in deeds 'close to and suspected of heresy, but not formal heresy'.109

The closest any of the suspects came to being associated with formal heresy was the last tried, Juan Núñez. Although arrested, like his co-religionists, for 'approving and following the sect of Alumbrados', during his trial it became clear that his heresies lay elsewhere. As testimony accrued the theological concern turned from Alumbradismo to suspicions of Lutheranism and eventually rested on allegations of Judaizing. His appearance in the auto de fe of 1603 was 'For lying and being vehemently suspected of keeping the Law of Moses' as well as 'other pernicious, erroneous, and offensive propositions', but never for Alumbradismo. ${ }^{110}$ Despite this change in accusation from Alumbradismo to Judaizing, how this happened demonstrates that it was not a conflation between Alumbradismo and judaizing practices. While Conversos could still be Alumbrados, the assumption that Alumbrados were always Conversos had largely fallen by the wayside. Furthermore, the allegations of Núñez as a Judaizer only came to light when his cellmate in the inquisitorial prison decided to denounce him to the inquisitors. Assisting the Inquisition in its pursuit of heretics was a well-known means of courting leniency for oneself. The witness utilized common and well-known conventions of Judaizing accusations to implicate Núñez, claiming that he wore clean clothes on Saturday, refused to eat pork, and gave greater esteem to the Old Testament than the New. ${ }^{111}$ In all likelihood, the recent burning of a number of Judaizers in the large 1596 auto de fe, including the infamous Luis de Carvajal, helped inform the witness' decision to accuse Núñez of this heresy in the belief that it would readily pique the Inquisition's interest. Therefore, the imprisonment of Núñez as an Alumbrado and his final punishment for Judaizing speaks more to dynamics functioning within the tribunal of New Spain at this time rather than understandings about the heresy of Alumbradismo.

Ultimately, the charge of Alumbradismo faltered in New Spain, at least in its first appearance. Despite clear resonance with the Alumbrados of Extremadura,

\footnotetext{
108 AGN, Vol. 180, exp. 1, fol. 194V.

109 AHN, book 1049, fols. 232V, 257.

110 AHN, book 1064, fols. 320v, 324V.

111 AGN, Vol. 210, exp. 2, fols. 74-77.
} 
and even Cordoba, the tribunal of New Spain did not find the charge appropriate for their current concerns and circumstances. Those imprisoned for 'approving and following the sect of Alumbrados' were ultimately punished for 'diverse crimes', lies and deceit', and at their most suspicious 'lying and vehemently suspect of guarding the Law of Moses'.112 What most differentiates those accused as Alumbrados in Spain in the wake of the 1574 Edict and this group in New Spain were the radically differing judgments by their local tribunals. Although every tribunal possessed the same inquisitorial definition of the heresy of Alumbradismo, how they chose to use it varied. In all likelihood, there were many factors and reasons why the threat of Alumbradismo failed to resonate with the tribunal of New Spain. However, one clear issue that sets this manifestation of alleged Alumbrados apart from those in Extremadura and Cordoba was the lack of willing persecutors. Unlike Cordoba, the tribunal of New Spain lacked personnel experienced in prosecuting Alumbrados as well as a laity attuned to this heresy based on recent preaching campaigns and public punishments. Whereas Extremadura, and later Cordoba, reaped the benefits of a zealous anti-Alumbrado crusader in the person of De la Fuente, in New Spain no such figure existed. The mere presence of ideas and discourses about heresy did not always result in the appearance of heretics. Until the participation of individuals, willing to denounce heresy coincided with the Inquisition's own interest, it was nearly impossible to pursue any group of heretics: 'the explanation lies not with the victims but with the persecutors.'113

\section{Conclusion}

The inquisitorial construction of the heresy of Alumbradismo originating in the 1520 s underwent significant developments over the course of the century. The result was that starkly different individuals and crimes were labeled as indicative of this heresy, depending on where and when it was discovered and prosecuted. Tracing this evolution makes it clear that Alumbradismo was never used as an all embracing accusation in the sixteenth century. Instead, it evolved in a linear manner as new information, allegations, and punishments were considered by the Inquisition and factored into the equation of what constituted Alumbradismo. Categories of heresy rarely emerged fully formed, and

\footnotetext{
112 AHN, book 1049, f.232v, 247v; book 1064, fol. $320 \mathrm{v}$.

113 Moore, Formation of a Persecuting Society, p. 63.
} 
the fact that the persecution of Alumbrados was 'subject to processes of historical modification and selection' does not prove that these were made carelessly. ${ }^{114}$ Rather than a sign of weakness, the adaptability of the Inquisition helped ensure its continuation across centuries and continents.

Tracing the evolution of the heresy of Alumbradismo through the course of the sixteenth century also illuminates a network of men in the employ of the Inquisition, or at the very least exposed to its process, who connect each of these individual appearances of this heresy into a coherent whole. The fact that the major appearances of Alumbradismo in the sixteenth century in Spain and New Spain can be connected, not only by the heretical crime they were accused of but also by a network tied to the Inquisition speaks volumes about the institution's organization of educated and religious men who were capable of spreading their ideas about heterodoxy amidst their efforts to police orthodoxy. While De la Fuente was clearly the most outspoken of these men his work was the product of other's earlier thinking about Alumbrado heretics and went on to heavily influence not only how other inquisitorial personnel, but also the Inquisition as an institution, understood this heresy. Despite the death of De la Fuente in 1592, Dominican calificadores continued to cite his work, assuring the Consejo of their qualifications to judge suspected Alumbrados 'because we have the papers of our Order, among them those of padre maestro fray Alonso de la Fuente.115 By the time the Edict of Faith against Alumbrados underwent its final revision in 1623 , it fully embraced the charges of sexual impropriety posited by De la Fuente decades earlier and maintained that Alumbrados did in fact claim to experience raptures and various forms of ecstatic fits although it remained silent on the issue of demonic participation. ${ }^{116}$

Ultimately, the necessary requisites for the prosecution of Alumbrados by the Inquisition included the dissemination of the inquisitorial discourse about this heresy and individuals, often but not always in the employ of the Inquisition, willing to pursue it. After the initial Edict of Faith in 1525, it is clear that this first ingredient was circulating. While lay accessibility varied, this inquisitorial construct achieved its greatest exposure in the wake of preaching campaigns and public punishments. Similarly, only following continuing appearances of the heresy did a cadre of inquisitorial personnel develop an expertise on Alumbradismo, leading to professional promotions of their own, which only encouraged them to continue to actively seek to root out these

\footnotetext{
114 Weber, 'The Inquisitor', p. 187; Moore, War on Heresy, p. 261.

115 AHN, Leg. 2960 s.f.; Huerga, Historia de los Alumbrados, Vol. II, pp. 96-97.

116 AHN, book 1231, fols. 648r-653v.
} 
heretics. Failing these components, as happened in New Spain, alleged Alumbrados were brushed aside as instances of deceit rather than heresy. If the individuals in Extremadura and Cordoba were Alumbrados, then so too were those accused in New Spain in the 1590s. The difference in how the charge of Alumbradismo was deployed, prosecuted, and ultimately judged, says more about the inquisitorial context in which these occurred, than the deviants it was meant to describe. 